\title{
UJI TOKSISITAS DAN SKRINING FITOKIMIA TEPUNG GABAH PELEPAH AREN (Arenga pinnata) ${ }^{1)}$
}

\author{
Meiske S. Sangi ${ }^{2)}$, Lidya I. Momuat ${ }^{2)}$, Maureen Kumaunang ${ }^{2)}$ \\ ${ }^{1)}$ Penelitian Dibiayai DIPA UNSRAT Tahun 2012 \\ ${ }^{2)}$ Program Studi Kimia FMIPA Universitas Sam Ratulangi \\ Jl. Kampus Unsrat Manado, 95115 \\ e-mail: meiske_sangi@yahoo.co.id; 1momuat@yahoo.com; maureen273@yahoo.com
}

\begin{abstract}
ABSTRAK
Telah dilakukan penelitian uji toksisitas dan skrining fitokimia tepung pelepah aren. Tepung pelepah aren secara tradisional digunakan oleh masyarakat Tomohon sebagai obat untuk menghilangkan gatal-gatal dan luka bakar pada kulit, namun pemanfaatan ini belum dikenal secara luas di Sulawesi Utara. Pemanfaatan tepung pelepah aren sebagai obat tradisional ini belum banyak dilaporkan dalam literatur bahkan belum ada yang meneliti tentang sifat toksik dan kandungan senyawa metabolit sekunder yang terdapat pada tepung pelepah aren. Tujuan penelitian dalam pengujian toksisitas adalah untuk mengetahui apakah tepung pelepah aren bersifat toksik atau tidak selanjutnya menentukan nilai $\mathrm{LC}_{50}$-nya untuk mengetahui jumlah konsentrasi penyebab ketoksikan tepung pelepah aren. Metode yang digunakan untuk pengujian toksisitas adalah dengan menggunakan larva udang jenis Artemia salina Leach. Dalam metode ini A. salina Leachdipakai sebagai bioindikator. Metode ini mudah dikerjakan, murah, waktu deteksi singkat dan dapat dipertanggungjawabkan. Hasil yang diperoleh dari ekstrak etanol tepung pelepah aren bersifat toksik dengan nilai $\mathrm{LC}_{50}$-nya adalah $6,295 \mathrm{ppm}$ dan hasil pengujian fitokimia menunjukkan bahwa tepung pelepah aren mengandungsenyawa metabolit sekunder yaitu alkaloid yang ditunjukkan dengan pembentukan endapan jingga ketika direaksikan dengan pereaksi dragendorf, triterpenoid yang ditunjukkan dengan perubahan warna jingga pada sampel dan tanin yang ditunjukkan dengan pembentukan endapan putih ketika direaksikan Gelatin.
\end{abstract}

Kata kunci: pelepah aren, skrining fitokimia dan uji toksisitas

\section{TOXICITY TEST AND PHYTOCHEMICAL SCREENING ON PALM SUGAR LEAF MIDRIB FLOUR (Arenga pinnata)}

\begin{abstract}
A study of toxicity test and phytochemical screening on sugar palm midrib flour had been conducted. The flour is traditionally used as medicine to relieve itching and skin burn, although the use is not widely known in North Sulawesi. Utilization of this flour as a traditional medicine had not been widely reported in the literatures and the toxicity and content of secondary metabolites contained in the sugar palm midrib had not been studied. The purpose of this research was to determine the toxicity of the flour and the value of $\mathrm{LC}_{50}$ in order to find the concentration that causes its toxicity. The research method involved the use of Artemia salina Leach shrimp larvae as a bioindicator. This method was easy to perform, inexpensive, had short detection time, and reliable. The results showed that the ethanol extracted flour was toxic and had $\mathrm{LC}_{50}$ value of $6,295 \mathrm{ppm}$. The phytochemical screening showed that the flour contained secondary metabolite of alkaloid which was indicated by orange precipitation by using reagent Dragendorf, of triterpenoid which was indicated by orange discoloration, and of tannin which was indicated by white precipitate by using gelatin.
\end{abstract}

Keywords: sugar palm midrib, phytochemical screening and toxicity test 


\section{PENDAHULUAN}

\section{Latar Belakang}

Indonesia kaya akan keanekaragaman hayati yang dapat dimanfaatkan dalam semua aspek kehidupan manusia. Obat tradisional adalah salah satu bentuk nyata pemanfaatan sumber daya hayati tersebut. Pemanfaatan keanekaragaman hayati dalam bentuk penggunaan obat-obat tradisional ini merupakan alternatif yang dinilai lebih ekonomis karena penggunaan obat-obatan yang diolah secara modern sulit dijangkau harganya oleh kebanyakan orang.

Tanaman aren merupakan sumber daya hayati yang banyak dimanfaatkan oleh masyarakat. Tanaman aren banyak tumbuh di daerah tropis seperti Sulawesi Utara. Berdasarkan informasi yang diperoleh dari masyarakat di Sulawesi Utara khususnya masyarakat Tomohon, tepung pelepah aren dapat dimanfaatkan sebagai obat tradisional untuk menghilangkan penyakit gatal-gatal dan luka bakar pada kulit. Namun pemanfaatan tepung pelepah aren sebagai obat tradisional belum banyak diketahui oleh masyarakat secara luas. Masyarakat Sulawesi Utara selama ini banyak memanfaatkan tanaman aren untuk pemenuhan kebutuhan hidup sehari-hari seperti batang dimanfaatkan sebagai bahan baku pembuatan kerajinan, ijuk dimanfaatkan dalam pembuatan sapu, daun dimanfaatkan sebagai bahan dekorasi, buah dimanfaatkan dalam pembuatan kolangkaling, air nira yang dihasilkan dimanfaatkan untuk pembuatan gula merah dan juga sebagai bahan utama untuk minuman tradisional beralkohol yang dikenal dengan sebutan cap tikus.

Pemanfaatan tepung pelepah aren sebagai obat tradisional ini belum banyak dilaporkan dalam literatur bahkan belum ada yang meneliti tentang sifat toksik dan kandungan senyawa metabolit sekunder yang terdapat pada tepung pelepah aren.

Pengujian toksisitas dilakukan untuk mengetahui apakah tepung pelepah aren bersifat toksik atau tidak selanjutnya menentukan nilai $\mathrm{LC}_{50}$-nya untuk mengetahui jumlah konsentrasi penyebab ketoksikan tepung pelepah aren. Salah satu metode yang baik digunakan untuk pengujian toksisitas adalah dengan menggunakan larva udang jenis Artemia salina Leach. Dalam metode ini A. salina Leachdipakai sebagai bioindikator. Metode ini mudah dikerjakan, murah, waktu deteksi singkat dan dapat dipertanggungjawabkan.

Sampel yang bersifat toksik disebabkan oleh adanya kandungan senyawa metabolit sekunder. Oleh karena itu dilakukan pengujian metabolit sekunder untuk mendeteksi golongan senyawa kimia yang terdapat dalam sampel. Metode ini merupakan salah satu dari pendekatan yang lazim digunakan untuk mencari komponen senyawa kimia tanaman yang memiliki aktivitas biologi. Biasanya, tanaman yang dapat dimanfaatkan sebagai obat memiliki sifat toksik (racun) terhadap penyakit karena adanya senyawa metabolit sekunder yang terdapat dalam tanaman tersebut.

\section{METODE PENELITIAN}

\section{Prosedur Penelitian}

\section{Ekstraksi tepung pelepah aren}

- Sebanyak 100 gram tepung pelepah aren dimasukkan ke dalam gelas kimia 1000 $\mathrm{mL}$, ditambahkan etanol sampai kirakira $1 \mathrm{~cm}$ diatas permukaan ekstrak, diaduk selama 5 menit kemudian didiamkan selama 24 jam.

- $\quad$ Saring menggunakan kertas saring jenis Whatman no. 42 dan filtratnya dimasukkan kedalam botol.

- Ampasnya ditambahkan lagi etanol sama seperti pada perlakuan no. 1

- $\quad$ Saring lagi seperti pada perlakuan no. 2 dan ditambahkan dalam botol pada perlakuan no.2, perlakuan dilakukan sampai filtrat kelihatan agak jernih.

- Filtrat tersebut dimasukkan dalam labu Evaporator yang telah ditimbang beratnya.

- Selanjutnya dievaporasi pada suhu maksimum $45{ }^{\circ} \mathrm{C}$ sampai diperoleh ekstrak etanol tepung pelepah aren yang pekat.

- Ekstrak yang diperoleh ditimbang dan disimpan dalam Desikator sebelum digunakan untuk pengujian toksisitas.

\section{Uji Toksisitas Menggunakan Larva}

\section{A. salina Leach}

Penyiapan Larva A. salinaLeach

Larva udang disiapkan dengan cara menetaskan telur $A$. salina Leach selama dua 
hari sebelum dilakukan pengujian. Penetasan dilakukan dengan cara merendam telur udang tersebut ke dalam gelas piala $1000 \mathrm{~mL}$ yang berisi air laut buatan. Air laut buatan dibuat dengan melarutkan $20 \mathrm{~g}$ garam tak beryodium ke dalam $1 \mathrm{~L}$ air kran, disaring dan diaerasi. Setelah 48 jam perendaman, telur menetas dan menghasilkan larva $A$. salina Leachyang siap digunakan dalam pengujian (Indrayani et al., 2006).

\section{Penyiapan Sampel}

Sebanyak $40 \mathrm{mg}$ ekstrak sampel, dilarutkan dengan $20 \mathrm{~mL}$ air laut buatan untuk membuat larutan uji dengan konsentrasi 2000 ppm. Dari larutan uji 2000 ppm, selanjutnya dibuat lagi larutan dengan konsentrasi 100, 50, 25 dan 12,5 ppm dengan cara pengenceran. Untuk kontrol $(0 \mathrm{ppm})$ dilakukan tanpa penambahan ekstrak (Sirait, 2001).

\section{Uji Toksisitas}

Larutan uji dengan konsentrasi 100, 50, 25 dan 12,5 ppm, masing-masing dipipet sebanyak $6 \mathrm{~mL}$ dimasukkan ke dalam tabung reaksi dan ditambahkan 10 ekor larva udang yang telah berumur 2 hari. Setiap konsentrasi dilakukan dua kali pengulangan dan dibandingkan dengan kontrol. Pengamatan I dilakukan selama 6 jam dengan selang waktu 1 jam. Selanjutnya pengamatan II dilakukan pada 12, 18 dan 24 jam. JumLah larva udang yang mati dihitung tiap 6,12, 18 dan 24 jam (Sirait, 2001). Analisis data perhitungan $\mathrm{LC}_{50}$ dilakukan dengan cara data $\%$ kematian ditransformasikan ke dalam log konsentrasi (Keostoni, 1985).

Uji golongan senyawa metabolit sekunder tepung pelepah aren (Houghton dan Raman, 1998 dan Miranda, 1986)

\section{Uji alkaloid}

Sampel sebanyak 0,05 g ekstrak etanol ditambahkan kloroform secukupnya, selanjutnya ditambahkan $10 \mathrm{~mL}$ amoniak dalam kloroform. Larutan disaring dan filtrat dimasukkan ke dalam erlenmeyer kemudian ditambahkan 10 tetes $\mathrm{H}_{2} \mathrm{SO}_{4} 2 \mathrm{M}$. Campuran dikocok dengan teratur, dibiarkan beberapa lama sampai terbentuk dua lapisan. Lapisan atas dipindahkan pada tiga tabung reaksi, masing-masing 2,5 mL. Ketiga larutan diuji dengan pereaksi Meyer, Dragendorf dan Wagner. Apabila terbentuk endapan menunjukkan bahwa sampel tersebut mengandung alkaloid, dengan pereaksi Meyer menghasilkan endapan berwarna putih, dengan pereaksi Dragendorf menghasilkan endapan berwarna merah jingga dan dengan pereaksi Wagner menghasilkan endapan berwarna coklat.

\section{Uji saponin.}

Ekstrak sebanyak $1 \mathrm{~mL}$ ditambah 10 $\mathrm{mL}$ air dikocok kuat-kuat. Sebagai blanko, digunakan $10 \mathrm{~mL}$ alkohol dan sedikit air. Bila pada tabung sampel terdapat buih setinggi 3,5 $\mathrm{cm}$ dan stabil selama 10 menit, maka ekstrak mengandung glikosida saponin.

\section{Uji Triterpen Steroida jenuh (uji Liebermann-Buchard)}

Sampel sebanyak 50-100 mg diletakkan pada plat tetes dan ditambahkan asam asetat sampai semua sampel terendam, dibiarkan 15 menit kemudian 6 tetes larutan dipindahkan ke dalam tabung reaksi dan ditambahkan 2-3 tetes asam sulfat pekat. Perubahan warna yang terjadi diamati dan intensitas warna yang dihasilkan digunakan sebagai ukuran relatif kandungan triterpenoid dan steroid dalam sampel. Adanya triterpenoid ditunjukkan dengan terjadinya warna merah jingga atau ungu, sedangkan adanya steroid ditunjukkan dengan terbentuknya warna biru.

\section{Uji Flavonoid}

Satu gram sampel dimasukkan dalam labu erlenmeyer dan ditambah etanol $25 \mathrm{~mL}$. Kemudian dipanaskan sampai mendidih dan disaring. Filtrat yang diperoleh diuapkan sampai volume pelarut tinggal setengahnya. Filtrat dibagi menjadi dua, tabung pertama blanko dan tabung kedua ditambah beberapa tetes etanol, dikocok kemudian ditambahkan serbuk magnesium dan teteskan $5 \mathrm{M}$ asam klorida. Bila timbul warna merah maka ekstrak mengandung flavonoid.

\section{Uji Tanin}

Sampel sebanyak 2 gram dihaluskan dan ditambahkan metanol dan di saring. Filtratnya ditambahkan $\mathrm{NaCl} 10 \%$ dan disaring. Filtrat dibagi menjadi 2 bagian. Masing-masing ditetesi dengan gelatin $10 \%$ dan $\mathrm{FeCl}_{3} 10 \%$. Jika ada endapan menunjukkan positif tanin sebaliknya jika 
tidak ada endapan menunjukkan negatif tanin.

\section{HASIL DAN PEMBAHASAN}

\section{Analisis toksisitas}

Hasil analisis untuk toksisitas dengan menggunakan larva udang A. salina $\mathrm{L}$. pada ekstrak etanol tepung pelepah aren dapat dilihat pada tabel 1 .

Tabel 1. Mortalitas larva padaekstrak etanol tepung pelepah aren

\begin{tabular}{|c|c|c|c|c|c|}
\hline $\begin{array}{c}\text { Waktu } \\
\text { (jam) }\end{array}$ & \multicolumn{5}{|c|}{ Konsentrasi (ppm) } \\
\cline { 2 - 6 } & $\mathbf{0}$ & $\mathbf{1 2 , 5}$ & $\mathbf{2 5}$ & $\mathbf{5 0}$ & $\mathbf{1 0 0}$ \\
\hline 1 & 0 & 0 & 0 & 0 & 0 \\
\hline 2 & 0 & 0 & 0 & 0 & 0 \\
\hline 3 & 0 & 0 & 0 & 0 & 0 \\
\hline 4 & 0 & 0 & 0 & 0 & 6,5 \\
\hline 5 & 0 & 4 & 3 & 7,5 & 7,5 \\
\hline 6 & 0 & 4 & 5 & 9 & 8,5 \\
\hline 12 & 0 & 4 & 7 & 10 & 10 \\
\hline 18 & 0 & 5 & 8,5 & 10 & 10 \\
\hline 24 & 0 & 7 & 8,5 & 10 & 10 \\
\hline$\%$ & 0 & $70 \%$ & $85 \%$ & $100 \%$ & $100 \%$ \\
Kematian $^{2}$ & 0 & $6,295 \mathrm{ppm}$ \\
\hline LC $_{50}$ & \multicolumn{7}{|c|}{} \\
\hline
\end{tabular}

Ket. Mortalitas larva diperoleh dari rata-rata dua ulangan

Pada perlakuan yang dilakukan, keadaan lingkungan dari setiap tabung kontrol dan tabung uji dibuat sama seperti pada waktu penetasan telur larva dengan cara tetap memberikan aerasi pada setiap tabung agar apabila terjadi kematian larva udang hal tersebut bukan disebabkan oleh daya tahan larva yang sudah menurun terhadap faktorfaktor luar akan tetapi kematian A. salina Leach disebabkan oleh sifat toksik dari ekstrak yang digunakan. Dari pengamatan dapat dilihat bahwa A. salina Leach yang berada pada kontrol tidak menunjukkan mortalitas.Pada tabung uji $100 \mathrm{ppm}$ mulai menunjukkan mortalitas pada jam ke 4 dan untuk tabung uji 12,$5 ; 25$ dan 50 ppm mulai menunjukkan mortalitas pada jam ke 5. Hal ini menunjukkan bahwa semakin besar nilai konsentrasi ekstrak, maka mortalitas pada $A$. salina Leach semakin besar. Hal ini sesuai dengan Lu (1995) yang menyebutkan bahwa setiap zat kimia bila diberikan dengan dosis yang cukup besar akan menimbulkan gejalagejala.Menurut Nurhayati et al. (2006), efek toksisitas dianalisis dari pengamatan dengan persen kematian.

$$
\% \text { Larva }=\frac{\text { Jumlah Larva yang Mati }}{\text { Jumlah LarvaUji }} \times 100 \%
$$

Dengan mengetahui kematian larva, kemudian dicari angka probit melalui Tabel dan dibuat persamaan garis:

$\mathrm{Y}=\mathrm{BX}+\mathrm{A}$

Dimana, $\mathrm{Y}=$ Log Konsentrasi dan $\mathrm{X}=$ Angka Probit.

Dari persamaan tersebut kemudian dihitung $\mathrm{LC}_{50}$ dengan memasukkan nilai probit (50\% kematian).

Berdasarkan hasil yang diperoleh pada tabel 1 menunjukkan bahwa banyaknya mortalitaslarva udang pada konsentrasi 0 ; 12,$5 ; 25$ dan 100 ppm dan persentasi mortalitas pada jam ke-24. Pada konsentrasi 0 ppm persentasi kematiannya sebesar $0 \%, 12,5$ ppm persentasi kematiannya sebesar 70\%, 25 ppm persentasi kematiannya sebesar $85 \%, 50$ ppm persentasi kematiannya sebesar $100 \%$ dan 100 ppm persentasi kematiannya sebesar $100 \%$. Grafik hubungan antara persentasi kematian larva dan nilai $\mathrm{LC}_{50}$ dapat dilihat pada Gambar 1.

Pada Gambar 1 terlihat persamaan regresi linear dari grafik di atas digunakan untuk mencari nilai $\mathrm{LC}_{50}$ dengan memasukkan angka $50 \%$ sebagai $\mathrm{x}$, sehingga diperoleh nilai $\mathrm{y}=1.817 \mathrm{x}-0.051$. Nilai $\mathrm{y}$ menunjukkan log konsentrasi dari ekstrak etanol. Konsentrasi ekstrak etanol adalah antilog dari 90.799 yaitu 6,295. Hal ini berarti kemampuan sampel untuk membunuh $50 \%$ dari A. salina Leach pada saat konsentrasi ekstrak mencapai 6,295 ppm.

Menurut Meyer dalam Astuti (2001) melaporkan bahwa suatu ekstrak menunjukkan aktivitas ketoksikan dalam uji toksisitas jika ekstrak dapat menyebabkan kematian 50\% hewan uji pada konsentrasi < $1000 \mathrm{ppm}$. Berdasar dari pernyataan tersebut maka ekstrak etanol dari tepung tangkai pelepah aren bersifat toksik. Hal ini ditunjukkan dari nilai $\mathrm{LC}_{50}$ yang diperoleh yaitu pada konsentrasi 6,295 ppm.

\section{Kandungan senyawa metabolit sekunder pada tepung tangkai pelepah aren}

Hasil Kandungan senyawa metabolit sekunderekstrak tepung pelepah aren dapat dilihat pada Tabel 2 berikut ini. 


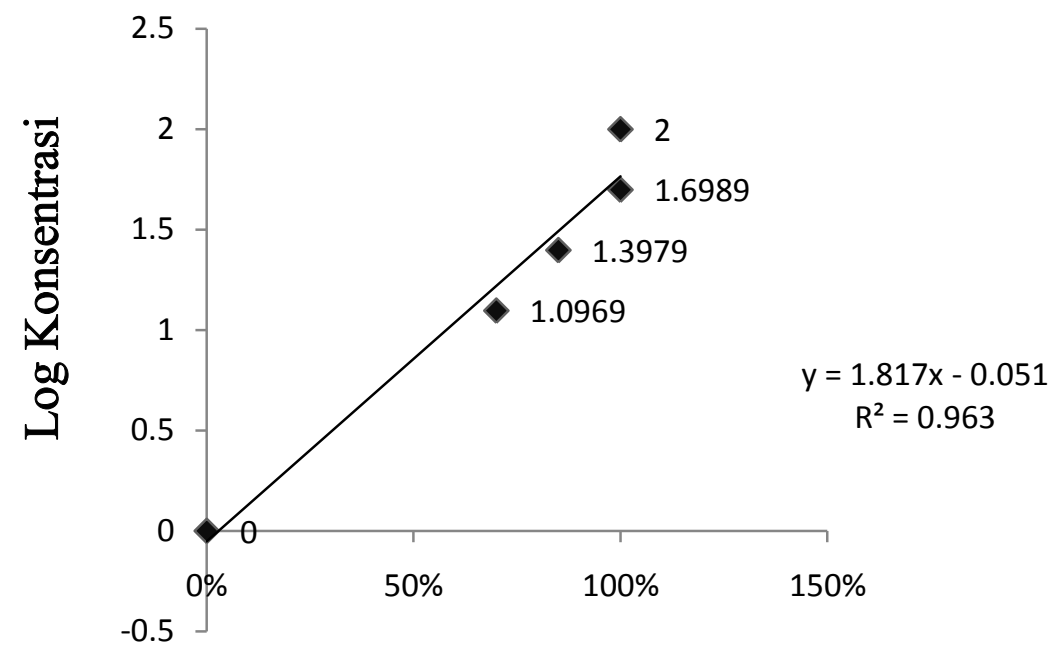

\section{Persentasi Kematian Larva}

Gambar 1. Grafik hubungan antara persentasi kematian larva dan nilai $\mathrm{LC}_{50}$

Tabel 2. Kandungan senyawa metabolit sekunder ekstrak etanol tepung pelepah aren.

\begin{tabular}{|l|l|l|c|c|l|}
\hline Senyawa & $\begin{array}{l}\text { Warna } \\
\text { Awal }\end{array}$ & Warna Akhir & Endapan & Hasil & Keterangan \\
\hline Alkaloid & $\begin{array}{l}\text { Keputih- } \\
\text { putihan }\end{array}$ & $\begin{array}{l}\text { Meyer: Bening } \\
\text { Dragendorf: Jingga } \\
\text { Wagner: Cokelat } \\
\text { Kehitaman }\end{array}$ & $\begin{array}{c}- \\
\text { Kuning } \\
-\end{array}$ & $\begin{array}{c}- \\
++ \\
-\end{array}$ & Terbentuk Endapan \\
\hline Saponin & $\begin{array}{l}\text { Cokelat } \\
\text { (Sampel) }\end{array}$ & Cokelat (Sampel) & $\begin{array}{c}\text { Cokelat } \\
\text { (Sampel) }\end{array}$ & - & Tidak terbentuk buih \\
\hline $\begin{array}{l}\text { Triterpenoid/ } \\
\text { Steroid }\end{array}$ & $\begin{array}{l}\text { Kuning } \\
\text { Pucat }\end{array}$ & Jingga & - & ++ & $\begin{array}{l}\text { Mengandung } \\
\text { Triterpenoid }\end{array}$ \\
\hline Flavonoid & $\begin{array}{l}\text { Kuning } \\
\text { Pucat }\end{array}$ & Kuning Pucat & - & - & $\begin{array}{l}\text { Serbuk Mg tidak } \\
\text { bereaksi. }\end{array}$ \\
\hline Tanin & $\begin{array}{l}\text { Kuning } \\
\text { Pucat }\end{array}$ & $\begin{array}{l}\text { FeCl } \text { Kuning } \\
\text { Kecokelatan } \\
\text { Gelatin: Putih Susu }\end{array}$ & $\begin{array}{l}\text { Kuning Tua } \\
\text { Putih }\end{array}$ & +++ & $\begin{array}{l}\text { Terjadi perubahan } \\
\text { warna dan } \\
\text { ada endapan. }\end{array}$ \\
\hline
\end{tabular}

Keterangan: (-): Tidak ada(++): Agak Banyak

$$
(+) \text { : Sedikit } \quad(+++) \text { : Banyak }
$$

Uji fitokimia ini dilakukan secara kualitatif dan hasilnya menunjukkan bahwa tepung pelepah aren mengandung beberapa senyawa metabolit sekunder yaitu alkaloid, triterpenoid dan tanin.

\section{Penapisan Alkaloid}

Pada penapisan alkaloid, penambahan pereaksi Meyer akan menyebabkan terbentuknya endapan berwarna putih yang menunjukkan hasil yang positif mengandung senyawa alkaloid. Proses yang sama juga dilakukan pada penambahan pereaksi Dragendorf dan Wagner. Pada pereaksi Dragendorf akan terbentuk endapan berwarna merah jingga sedangkan untuk pereaksi Wagner akan terbentuk endapan berwarna coklat.Prinsip dari metode analisis ini adalah reaksi pengendapan yang terjadi karena adanya penggantian ligan.Atom nitrogen yang mempunyai pasangan elektron bebas pada alkaloid dapat mengganti ion iodo dalam pereaksi-pereaksi tersebut.Pereaksi Meyer mengandung merkuri klorida dan kalium iodida. Pereaksi Dragendorf mengandung 
kalium iodida dan bismuth subnitrat dalam asam asetat glasial. Pereaksi Wagner mengandung iod dan kalium iodida. Dalam pengujian ini yang terbentuk endapan adalah dengan pereaksi dragendorf. Diduga hal ini disebabkan oleh karena kandungan senyawa alkaloid yang sedikit pada sampel sehingga hanya satu pereaksi yang sensitif bereaksi terhadap sampel (persamaan reaksi1).

Persamaan Reaksi 1:

Pereaksi Dragendorf: $\mathrm{Bi}\left(\mathrm{NO}_{2}\right)_{3}+4 \mathrm{KI} \rightarrow \mathrm{K}_{3}\left[\mathrm{BiI}_{4}\right]+\mathrm{KNO}_{2}$

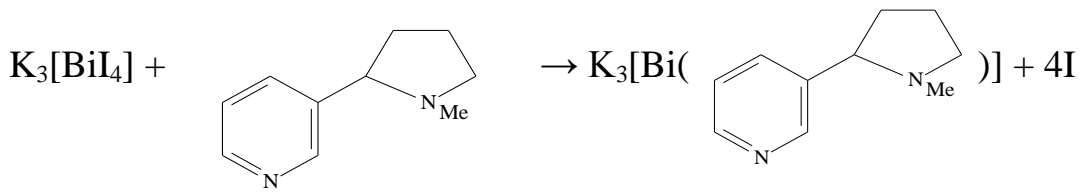

\section{Penapisan Saponin}

Arcuri dalam Makang (2005), menyatakan saponin memiliki glikosil yang berfungsi sebagai gugus polar dan gugus terpenoid/steroid sebagai gugus non-polar. Senyawa yang memiliki gugus polar dan nonpolar bersifat aktif permukaan sehingga saat dikocok dengan air saponin dapat membentuk misel. Pada struktur misel, gugus polar menghadap ke luar sedangkan gugus nonpolarnya menghadap ke dalam. Keadaan inilah yang tampak seperti busa, namun dalam analisis ini sampel tidak memiliki kemampuan untuk membentuk busa.

Persamaan Reaksi 2:<smiles>CC(=O)OC(C)=O</smiles><smiles>CC1CCC(C(C)C)C(O)C1</smiles>

\section{Penapisan Flavonoid}

Robinson (1995), menyatakan bahwa penambahan serbuk magnesium dan asam klorida pada pengujian flavonoid akan menyebabkan tereduksinya senyawa flavonoid yang ada sehingga menimbulkan reaksi warna merah yang merupakan ciri adanya flavonoid pada sampel. Namun dalam analisis ini serbuk $\mathrm{Mg}$ tidak memberikan reaksi reduksi senyawa flavonoid sehingga larutan uji tidak memberikan perubahan warna.

\section{Penapisan Terpenoid/Steroida Jenuh}

Kandungan terpenoid/steroid dalam tumbuhan diuji dengan menggunakan metode Liebermann-Buchard (asam asetat) yang nantinya akan memberikan warna merah jingga atau ungu untuk terpenoid dan biru untuk steroid. Pada penambahan pereaksi Liebermann-Buchard, molekul-molekul asam anhidrida asetat dan asam sulfat akan berikatan dengan molekul senyawa terpenoid/steroid sehingga menghasilkan reaksi yang tampak pada perubahan warna. Dari hasil penapisan terpenoid dan steroid yang dilakukan, ternyata sampel mengandung senyawa terpenoid (persamaan reaksi 2). 
Persamaan Reaksi 3:<smiles>CC[C@H](Cl)[C@H](C)Oc1cc(C(=O)O)cc(O)c1OCCOc1c(O)cc(C(=O)O)cc1O</smiles>

\section{KESIMPULAN DAN SARAN}

\section{Kesimpulan}

1. Ekstrak etanol tepung pelepah aren bersifat toksik dengan nilai $\mathrm{LC}_{50}$-nya adalah 6,295 ppm.

2. Hasil pengujian fitokimia menunjukkan bahwa tepung pelepah aren mengandungsenyawa metabolit sekunder yaitu alkaloid yang ditunjukkan dengan pembentukan endapan jingga ketika direaksikan dengan pereaksi dragendorf, triterpenoid yang ditunjukkan dengan perubahan warna jingga pada sampel dan tanin yang ditunjukkan dengan pembentukan endapan putih ketika direaksikan Gelatin .

\section{Saran}

Perlu dilakukan penelitian lebih lanjut mengenai struktur senyawa aktif yang terkandung dalam tepung tangkai pelepah aren.

\section{DAFTAR PUSTAKA}

Ajay, M., H. M. Cheng, A. M. Mustafa dan M. R. Mustafa. 2005. A Comparative Study on Antioxidant Activity of Flavonoids: $\quad$ Structure-Activity Relationships. Malaysian Journal of Science (24): 187-190

Anonim. 2000. Parameter Standar Umum Ekstrak Tumbuhan Obat. Departemen Kesehatan Republik Indonesia Rektorat Jenderal Pengawasan Obat dan Makanan, Direktorat Pengawasan Obat Tradisional. Jakarta.
Astuti, M. D. 2001. Penapisan Metabolit Sekunder Pada Limbah Ekstrak Air Tubuh Ganoderma lucidum Dengan Uji Toksisitas Larva Udang (Artemia salina Leach) [skripsi]. FMIPA. IPB, Bogor.

Burda, S. dan W. Oleszek. 2001. Antioxidant and Antiradical Activities of Flavonoids. J. Agric. Food Chem. 49: 2774-2779.

Dinas Perkebunan. 2007. Budidaya Tanaman Aren.

http://petaniwahid.blogspot.com/2008 $08 \quad 01$ _archive.htmL[11 Agustus 2009]

Gunawan, D dan S. Mulyani. 2004. Ilmu Obat Alam (Farmakognosi) Jilid 1. Penebar Swadaya. Jakarta.

Harborne, J.B. 1987. Metode Fitokimia, Penuntun Cara Moderen Menganalisis Tumbuhan. Terjemahan K. Pahmawinata dan I. Soediro, ITB. Bandung.

Houghton, P.J. dan A. Raman. 1998. Laboratory Handbook for the Fractionation of Natural Extracts. Chapman \& Hall. London.

Indrayani, L., Soetjipto, H., Sihasale, L. 2006. Skrining Fitokimia dan Uji Toksisitas Ekstrak Daun Pecut Kuda (Stachytarpheta jamacensis L. Vahl) Terhadap Larva Udang Artemia Salina Leach. Fakultas Sains dan Matematika Universitas Kristen satya Wacana, Salatiga. Journal. 12 : 57-61.

Koestoni, T. 1985. Analisis Probit, Kelompok Peneliti Hama. Balai Penelitian Hortikultura. Lembang. 
Lu, F.C. 1995. Toksikologi Dasar. Asas, Organ Sasaran, dan Penilaian Resiko. Edisi ke-2. Terjemahan Edi Nugroho. UI, Jakarta.

Mamahit, C. 2009. Analisis Senyawa Metabolit Sekunder dan Uji Toksisitas pada Ekstrak Etanol Tepung tangkai pelepah aren (Spilanthes acmella L.). [skripsi]. FMIPA UNSRAT. Manado.

Makang, V.M.A. 2005. Analisis Fitokimia Tumbuhan Obat di Kabupaten Minahasa Utara. [Skripsi]. FMIPA UNSRAT. Manado.

Miranda, S.R. 1986. The Phytochemical, Microbiological Screening of Medical Plant. Unesco University of Philipines.
Mursyidi, A. 1990. Analisis Metabolit Sekunder. UGM Press. Yogyakarta.

Nurhayati, A., Nurlita, A., Rachmat, F. 2006. Uji Toksisitas Ekstrak Euchema Alvarezii terhadap Artemia Salina sebagai Studi Pendahuluan Potensi Anti Kanker. Fakultas Matematika dan Ilmu Pengetahuan alam Institut Teknologi Sepuluh November, Surabaya. Akta Kimindo Vol. 2 (1): 41-46.

Oey Kam Nio. 1989. Zat-zat Toksik Yang Secara Alamiah Ada Pada Bahan Makanan Nabati. http://www. kalbe.co.id. [6 Oktober 2009] 